\title{
Predictive Performance of Alternative Inflation Forecasting Models: New International Evidence
}

\author{
Unro Lee \\ University of the Pacific
}

Inflation rate and its volatility have been at a subdued level for most industrialized and emerging countries since the mid-1990s. The objective of this study is to evaluate the predictive performance of three alternative inflation forecasting models -- univariate time-series (ARIMA) model, Phillips curve model, and nä̈ve model -- for a selected number of inflation-targeting countries and non-inflation targeting countries over the period 1998-2015, a unique period marked by relatively low and stable inflation rate. It is found that out-of-sample inflation forecasts generated by ARIMA model are more accurate than those generated by the other two forecasting models for the majority of these countries. This study concludes, that during the period of low inflation rate, the central bank should weigh inflation forecasts obtained from a simple time-series model, such as ARIMA model, more heavily in its decisionmaking process.

\section{INTRODUCTION}

Inflation rate has been at a relatively subdued level for most industrialized and emerging countries since the mid-1990s. For example, average annual inflation rate for the United States was $6.54 \%$ between 1970 and 1989 , but the rate dropped to $3.08 \%$ during the period $1990-1999$, to $2.54 \%$ during the period 2000-2009, and to $1.86 \%$ between 2010 and 2015. ${ }^{1}$ Average annual inflation rate for the European Union was $6.48 \%$ during the period 1970-1996 and the rate has declined to $2.48 \%$ between 1997 and $2018{ }^{2}$

The precipitous drop in the inflation rate since the 1970 s can be easily discerned from the following two figures. Figure 1 presents the average annual inflation rate for the world economies as measured by changes in the consumer price index for the period 1969-2017. The world inflation rate had been at a heightened level and displayed significant volatility well until the mid-1990s and the rate then plummeted very rapidly until 1997. Since then, the world inflation rate has remained at a relatively low level. 
FIGURE 1

AVERAGE INFLATION RATE FOR WORLD ECONOMIES, 1969- 2017

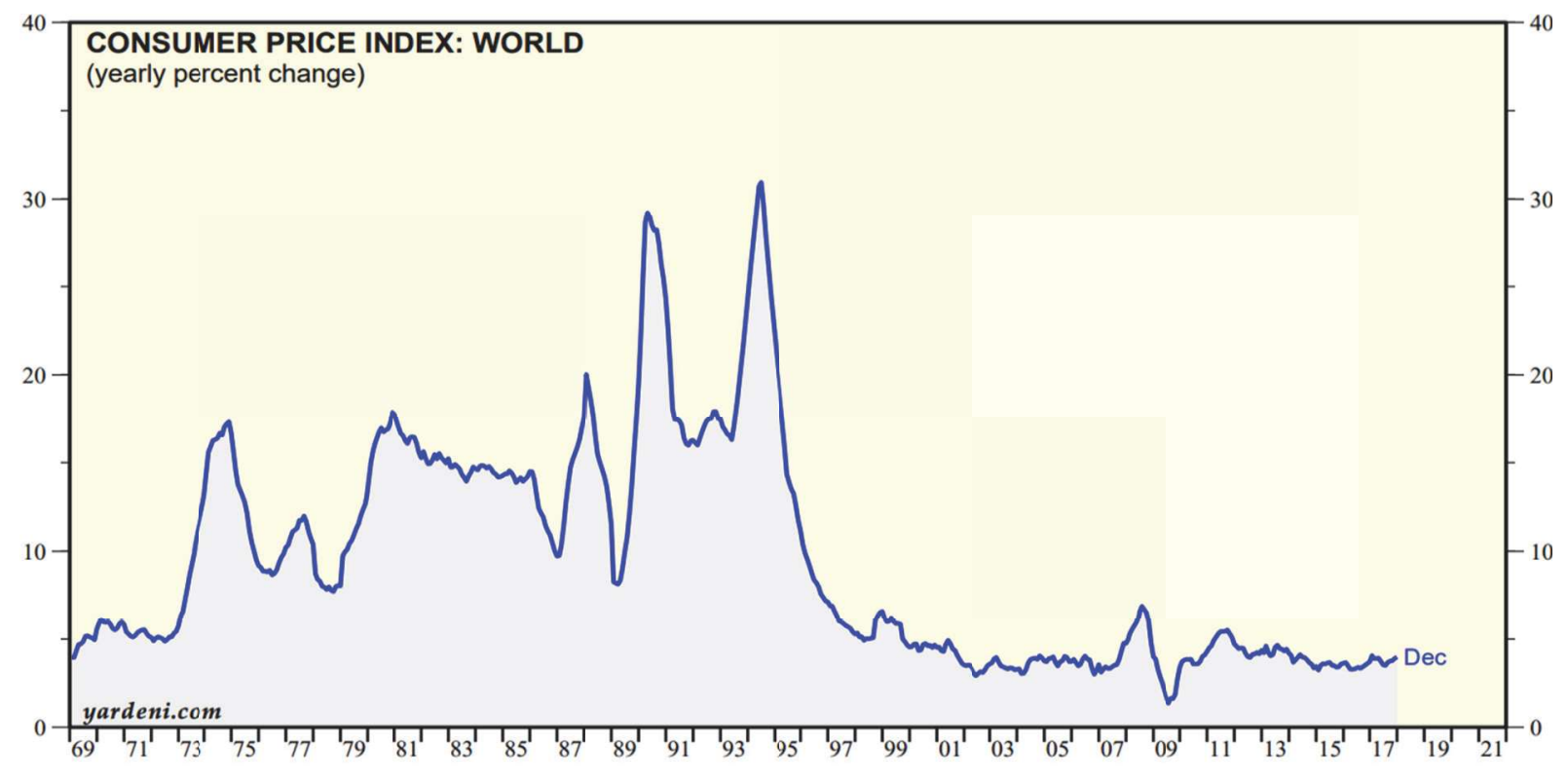

Source: IMF.

The trend of inflation rate for OECD countries, as can be seen in Figure 2, bears some resemblance to that of the world economies during the same period. Although the average annual inflation rate for these countries was hovering at double digit level until the early $1980 \mathrm{~s}$, the rate had exhibited a downward trend from the late 1980s until the middle of 1990s and has remained at a low level thereafter.

FIGURE 2

AVERAGE INFLATION RATE FOR OECD COUNTRIES, 1970-2017

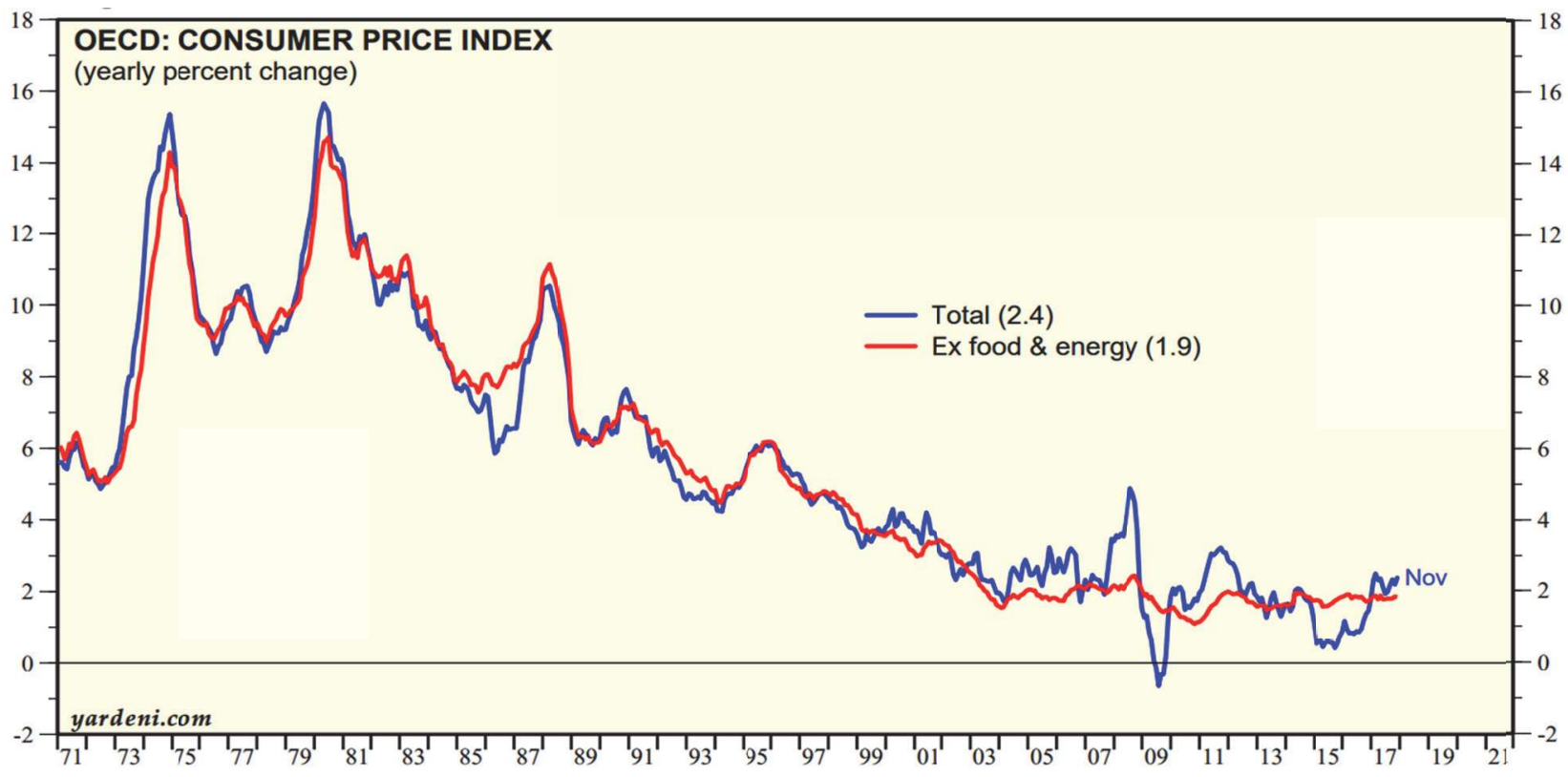

Source: Organization for Economic Cooperation \& Development (OECD). 
There are myriad reasons for persistently low, stable inflation rate for most countries during the last two decades, ranging from rapid technological advances (resulting in gradual reduction in computing costs) ${ }^{3}$, globalization (increased competitiveness of world economy, led by low-cost Chinese manufacturing $)^{4}$, dissipation of unionization in the private sector and concomitant dilution of collective wage bargaining power ${ }^{5}$, proliferation of part-time jobs at the expense of shrinking high-paying full-time jobs $^{6}$, widespread adoption of "inflation targeting" monetary policy", and reemergence of "secular stagnation". 8

Central banks of most countries have a mandate from the government to maintain price stability over time. These countries readily espouse the view that low and stable inflation rate will reduce inflation volatility, which will promote efficient allocation of resources and encourage household savings and firms' investment in physical assets, thereby contributing to maximum employment and sustainable longterm economic growth. For some countries, the mandate granted to the central bank is stringent and precise. Inflation targeting countries accord the central bank the authority to assign an explicit numerical target for the inflation rate and implement an appropriate monetary policy to achieve its inflation target. The proponents of inflation targeting policy has long maintained that inflation targeting would not only reduce inflation rate and its volatility, but also enhance both the transparency and accountability of the monetary policy. 29 countries have adopted inflation targeting policy since 1990. $\quad$ Many of these countries adopted inflation targeting policy after discretionary monetary policies they previously implemented failed to either stabilize or curb escalating inflation rate. ${ }^{10}$

Central banks of other countries, although not explicitly targeting inflation rate, nevertheless strive to promote sustainable, healthy economic growth and stability of inflation rate. For example, European Central Bank (ECB), which serves as a de facto central bank of Eurozone, a monetary union comprised of 19 European Union (EU) members that have adopted Euro as the common currency, does not specifically target inflation rate, but endeavors to maintain inflation rate of below, but close to $2 \%$, over the medium term (i.e., about three years). Swiss National Bank, the central bank for Switzerland, also actively pursues price stability, with annual inflation rate of less than $2 \%$, over the medium term. However, the Bank has also made it clear that setting a specific inflation target is not its main objective.

In these countries, the efficacy of the monetary policy in achieving price stability hinges invariably on the degree of accuracy with which the central bank predicts the future course of inflation rate. If the central bank predicts a sustained increase in inflationary expectation due to robust economic activity and escalating wages, then the bank will attempt to raise short-term interest rate to cool the overheated economy. On the other hand, in the event the central bank foresees declining inflationary expectation due to weakening economic activity, then the bank will implement accommodative monetary policy (i.e., lowering short-term interest rate) to rejuvenate the ailing economy.

Central bank obviously has ample resources (both financial and human) at its disposal to produce forecasts from a wide array of inflation forecasting models, ranging from simple ARIMA model to highly sophisticated multi-equation econometric models, such as Dynamic Stochastic General Equilibrium (DSGE) model. Economists employed by the central bank generally prefer sophisticated large-scale econometric models as the apparatus to generate inflation forecasts since these models are inherently better able to capture the complexity of a given economy. However, during the era of relatively stable inflation rate, inflation forecasts generated by a time-series model, such as ARIMA model, could fare better than those generated by other forecasting models since ARIMA model of inflation rate only utilizes past data on inflation. This assertion is supported by Edge and Gurkaynak (2010) who finds that DSGE model does a very poor job in forecasting both inflation rate and GDP growth rate for the United States during the period 1992-2004.

The objective of this study is to evaluate the predictive performance of three alternative inflation forecasting models - univariate time-series model, Phillips curve model, and naïve model- for a broad swath of countries over the period 1998-2015, a unique period marked by low and stable inflation rate. Specifically, this study will focus on a selected number of inflation-targeting countries (Australia, Canada, Israel, New Zealand, South Korea, Sweden, and the United Kingdom) and non-inflation targeting countries (France, Germany, Japan, Switzerland, and the United States). Seven inflation targeting 
countries are specifically chosen for this study because at least 15 years have elapsed since these countries formally adopted "inflation targeting" monetary policy. As such, ample data are readily available for these countries to ensure reliable empirical results.

This study finds that ARIMA model yields the most accurate inflation forecasts for the majority of these countries during the recent era of low inflation. The result of this study obviously carries an important policy implication since it is widely expected that the inflation rate for most advanced and emerging countries will continue to remain at a relatively subdued level for the foreseeable future. Federal Reserve Bank in September 2017 predicts that the US inflation rate will stay at 1.9\% for 2018 and at 2\% for both 2019 and 2020. IMF predicts that the global inflation rate will hover around $3.2 \%$ between 2018 and 2022.

Section II describes three alternative inflation forecasting models employed in this study. Section III discusses data used in this study and provides summary statistics. The empirical findings are presented in Section IV. The paper concludes with a brief summary of the paper in Section V.

\section{INFLATION FORECASTING MODELS}

Three alternative inflation forecasting models - time-series (ARIMA) model, Phillips curve model, and naïve model - utilized in this study are described in some detail in this section. Time-series (ARIMA) model has been used extensively in the literature to forecast inflation rate. Hafer and Hein (1990) report that time-series models generate more accurate forecasts of inflation rate than interest-rate models for six industrialized countries, while Ang, Bekaert and Wei (2007) and Stock and Watson (2007) document that ARIMA models outperform term-structures forecasting models and perform equally as well as Phillips curve models in predicting inflation rate for the United States.

IMA $(1,1)$ model is fitted in this study to both the monthly and quarterly data on inflation rate for all twelve countries in this study. IMA(1,1) model has the following specification:

$\pi_{\mathrm{t}}-\pi_{\mathrm{t}-1}=\mu+\varepsilon_{\mathrm{t}}-\theta \varepsilon_{\mathrm{t}-1}$,

where $\pi_{\mathrm{t}}$ is the inflation rate defined as $\log \left(\mathrm{p}_{\mathrm{t}} / \mathrm{p}_{\mathrm{t}-1}\right), \mathrm{p}_{\mathrm{t}}$ is the CPI (Consumer Price Index) at time $\mathrm{t}, \mu$ is a constant, and $\varepsilon_{\mathrm{t}}$ is a random disturbance (white noise) term.

Hafer and Hein $(1985,1990)$ find that $\operatorname{IMA}(1,1)$ process fits inflation rate very well for six industrialized countries - Belgium, Canada, England, France, Germany, and the United States. They also claim that Q-statistics of IMA $(1,1)$ models for all six countries do not reject the null hypothesis of white noise residuals. Stock and Watson (2007) also show that modeling U.S. inflation rate as IMA(1,1) process generates very accurate forecasts, especially since the late 1980s. Ang, Bekaert and Wei (2007) further documents that modeling U.S. inflation rate as $\operatorname{ARMA}(1,1)$, a stationary process, yields forecasts not significantly different than those obtained from $\operatorname{IMA}(1,1)$ model of inflation rate.

Stock and Watson (1999) find that the Phillips curve model outperforms time series forecasting models for the United States for the period 1959-1997. The Phillips curve model posits that inflation rate depends not only on past inflation rates, but also on other lagged macroeconomic variables such as real economic activity or unemployment rate ${ }^{11}$. The following version of the Phillips curve model of inflation rate is estimated in this study:

$\Delta \pi_{\mathrm{t}}=\alpha+\beta(\mathrm{L}) \Delta \mathrm{X}_{\mathrm{t}}+\gamma(\mathrm{L}) \Delta \pi_{\mathrm{t}}+\varepsilon_{\mathrm{t}}$,

where $\pi_{t}$ is the inflation rate at time $t, X_{t}$ is the real economic activity variable at time $t$, and $\beta(L)$ and $\gamma(\mathrm{L})$ are lag operators representing the number of lagged (differenced ) real economic activity and inflation rate variables, respectively. This is the model utilized by Orphanides and van Norden (2005) and Stock and Watson (2007) to forecast the inflation rate. Furthermore, both Stock and Watson (1999) and Ang, Bekaert, and Wei (2007) find that a simple Phillips curve model utilizing only past inflation rates 
and lagged GDP growth rates performs best among the alternative versions of Phillips curve models for the United States.

Atkeson and Ohanian (2001), Fisher, Liu and Zhou (2002), Orphanides and van Norden (2005), and Stock and Watson (2007) also document that naïve forecasting models have outperformed Phillips curve models for the United States since the early 1980s. Therefore, the following naïve forecasting model is also employed in this study:

$\Pi_{\mathrm{t}}=\pi_{\mathrm{t}-1}$

As stated before, central banks are deeply committed to maintain stable and low inflation rate over an extended period of time. Given there exists long and variable lags for monetary policy to exert a significant influence on the real economic activity and inflation rate, central bank must be able to predict with some degree of accuracy future inflation rates over longer horizon (e.g., 1- year or 2-year period). As such, this study also evaluates one-year-ahead forecasts of inflation rate from three alternative inflation forecasting models. However, specification of these three models - time-series model, Phillips curve model and naïve model - has to be modified slightly in order to generate one-year-ahead inflation forecasts.

IMA(1,1) model of inflation can be modified as

$\Pi_{\mathrm{t}+\mathrm{h}, \mathrm{t}}-\pi_{\mathrm{t}}=\mu+\varepsilon_{\mathrm{t}}-\theta \varepsilon_{\mathrm{t}-1}$,

where $\Pi_{t+h, t}$, one-year-ahead inflation rate, is defined as $\log \left(\mathrm{p}_{\mathrm{t}+12} / \mathrm{p}_{\mathrm{t}}\right)$ for the monthly forecasting model and as $\log \left(\mathrm{p}_{\mathrm{t}+4} / \mathrm{p}_{\mathrm{t}}\right)$ for the quarterly forecasting model. Likewise, $\pi_{\mathrm{t}}$, annualized inflation rate, is defined as $\log \left(\mathrm{p}_{\mathrm{t}} / \mathrm{p}_{\mathrm{t}-12}\right)$ for the monthly forecasting model and as $\log \left(\mathrm{p}_{\mathrm{t}} / \mathrm{p}_{\mathrm{t}-4}\right)$ for the quarterly forecasting model. Naïve model can now be characterized as

$\prod_{\mathrm{t}+\mathrm{h}, \mathrm{h}}=\pi_{\mathrm{t}}$

and the Phillips curve model as

$\Pi_{\mathrm{t}+\mathrm{h}, \mathrm{t}}-\pi_{\mathrm{t}}=\alpha+\beta(\mathrm{L}) \Delta \mathrm{X}_{\mathrm{t}}+\gamma(\mathrm{L}) \Delta \pi_{\mathrm{t}}+\varepsilon_{\mathrm{t}}$

where $X_{t}$ is the real economic activity variable at time $t$, and $\beta(L)$ and $\gamma(L)$ are lag operators representing the number of lagged (differenced) real economic activity and inflation rate variables, respectively.

\section{DATA AND SUMMARY STATISTICS}

Monthly data for inflation rate for nine countries -- Canada, France, Germany, Israel, Japan, South Korea, Sweden, United Kingdom and United States -- and quarterly data for inflation rate for twelve countries -- Australia, Canada, France, Germany, Israel, Japan, New Zealand, South Korea, Sweden, Switzerland, United Kingdom and United States -for the period 1998 - 2015 are obtained from the International Financial Statistics (IFS) database published by the International Monetary Fund (IMF). The monthly data for inflation rate are not available for Australia, New Zealand and Switzerland.

The IFS database provides quarterly but not monthly data for real GDP. Since both monthly and quarterly data for industrial production for these countries are readily available from the IFS database, industrial production is used in this study as a proxy for real GDP.

As previously stated, seven inflation-targeting countries - Australia, Canada, Israel, New Zealand, South Korea, Sweden, and United Kingdom -- are specifically chosen for this study because at least 15 years have elapsed since these countries formally implemented "inflation targeting" strategy. Five countries that are not explicitly targeting inflation rate - France, Germany, Japan, Switzerland, and United States - have also been chosen for this study.

Journal of Applied Business and Economics Vol. 20(6) 2018165 
France and Germany are two dominant members of Eurozone, which is comprised of 19 European Union member states that have adopted Euro as their common currency, and their conduct of monetary policy is carefully coordinated by the European Central Bank (ECB). Although the ECB has not formally adopted inflation targeting, its primary objective is to maintain price stability, preferably achieving annual inflation rate of less than $2 \%$ over the medium term (about three years). Inflation rate that ECB monitors is the Harmonised Index of Consumer Prices (HICP). ${ }^{12}$ Swiss National Bank (SNB), which is the Switzerland's central bank, also aims to maintain price stability with annual inflation of less than $2 \%$ over the medium term.

Although the United States was resistant to adopting inflation targeting in the past, Ben Bernanke, the Chairman of the Federal Reserve Board between 2006 and 2014, was a fierce advocate of inflationtargeting policy. Bernanke had made it clear through his writing and speeches that the Federal Reserve Bank should strive to keep the core inflation rate, i.e., inflation rate excluding prices of food and energy, between $1 \%$ and $2 \%$ annually in order to permanently lower inflationary expectation and foster sustainable economic growth ${ }^{13}$. United States formally adopted inflation targeting in January 2012 and has set $2 \%$ as the official target for inflation. Federal Reserve at the time assured that targeting inflation explicitly at the rate of $2 \%$ is fully consistent with the Federal Reserve's statutory mandate of promoting price stability and maximum employment over the longer horizon.

Bank of Japan, the central bank of Japan, had for long time refused to succumb to the pressure by the academic community to adopt inflation targeting policy primarily due to the concern that the Bank will lose independence in its decision-making process while the country was mired in prolonged economic slump. However, the Bank began implementing inflation targeting policy effective January 2013 with an expressed inflation target of $2 \%$ per year. Bank of Japan states in its website that imposing an explicit "target" for inflation rate ensures flexibility in its conduct of monetary policy. ${ }^{14}$

TABLE 1

\section{SUMMARY STATISTICS FOR INFLATION RATE: MONTHLY AND} QUARTERLY RESULTS FOR THE PERIOD 1970-2015.

\begin{tabular}{lcc}
\hline & \multicolumn{2}{c}{ Inflation Rate } \\
& Mean (\%) & Standard Deviation (\%) \\
\hline A. Monthly Results: & & \\
1. Canada: & & .408 \\
1970:1-1997:12 & .449 & .370 \\
1998:1-2015:12 & .156 & .419 \\
1970:1-2015:12 & .334 & \\
& & .387 \\
2. France: & & .298 \\
1970:1-1997:12 & .507 & .403 \\
1998:1-2015:12 & .115 & \\
1970:1-2015:12 & .353 & \\
& & .318 \\
3. Germany: & & 1.648 \\
1970:1-1997:12 & .173 & \\
1998:1-2015:12 & .114 & .51 \\
1970:1-2015:12 & .149 & 3.460 \\
4. Israel: & &
\end{tabular}




\section{Inflation Rate \\ Mean (\%) Standard Deviation (\%)}

\section{Japan:}

1970:1 - 1997:12

1998:1 - 2015:12

.35

.730

1970:1 - 2015:12

.0004

.319

.21

.627

6. South Korea:

1970:1 - 1997:12

1998:1 - 2015:12

.771

.944

1970:1 - 2015:12

.221

.414

.555

.825

7. Sweden:

1970:1 - 1997:12

1998:1 - 2015:12

.557

.636

1970:1 - 2015:12

.089

.412

.374

.604

8. United Kingdom:

1970:1 - 1997:12

1998:1 - 2015:12

.319

.493

.162

.363

1970:1 - 2015:12

.218

.420

9. United States:

1970:1 - 1997:12

1998:1 - 2015:12

.433

.384

.177

.330

1970:1 - 2015:12

.333

.373

\section{B. Quarterly Results:}

\section{Australia:}

1970:2 - 1997:4

1998: $1-2015: 4$

1.74

.67

1.19

1970:2 - 2015:4

1.32

.53

1.11

2. Canada:

1970:2 - 1997:4

1998:1 - 2015:4

1.35

.47

1.00

.91

1970:2 - 2015:4

.58

.91

3. France:

1970:2 - 1997:4

1.52

1.03

1998: 1 - 2015:4

.35

.42

1970:2 - 2015:4

1.06

1.02

4. Germany:

1970:2 - 1997:4

1998:1 - 2015:4

.72

.64

1970:2 - 2015:4

.33

.45

.46 


\begin{tabular}{|c|c|c|}
\hline & \multicolumn{2}{|c|}{ Inflation Rate } \\
\hline & Mean (\%) & Standard Deviation (\%) \\
\hline \multicolumn{3}{|l|}{ 5. Israel: } \\
\hline $1970: 2-1997: 4$ & 9.75 & 10.69 \\
\hline $1998: 1-2015: 4$ & .51 & 1.04 \\
\hline $1970: 2-2015: 4$ & 6.11 & 9.49 \\
\hline \multicolumn{3}{|l|}{ 6. Japan: } \\
\hline $1970: 2-1997: 4$ & 1.06 & 1.39 \\
\hline $1998: 1-2015: 4$ & -.01 & .54 \\
\hline $1970: 2-2015: 4$ & .64 & 1.24 \\
\hline \multicolumn{3}{|l|}{ 7. New Zealand: } \\
\hline $1970: 2-1997: 4$ & 2.13 & 1.52 \\
\hline $1998: 1-2015: 4$ & .51 & .54 \\
\hline $1970: 2-2015: 4$ & 1.49 & 1.46 \\
\hline \multicolumn{3}{|l|}{ 8. South Korea: } \\
\hline $1970: 2-1997: 4$ & 2.29 & 2.14 \\
\hline 1998:1 - 2015:4 & .69 & .76 \\
\hline $1970: 2-2015: 4$ & 1.67 & 1.90 \\
\hline \multicolumn{3}{|l|}{ 9. Sweden: } \\
\hline $1970: 2-1997: 4$ & 1.67 & 1.15 \\
\hline $1998: 1-2015: 4$ & .27 & .58 \\
\hline $1970: 2-2015: 4$ & 1.12 & 1.19 \\
\hline \multicolumn{3}{|l|}{ 10. Switzerland: } \\
\hline $1970: 2-1997: 4$ & .31 & .41 \\
\hline $1998: 1-2015: 4$ & .05 & .36 \\
\hline $1970: 2-2015: 4$ & .21 & .41 \\
\hline \multicolumn{3}{|c|}{ 11. United Kingdom: } \\
\hline $1970: 2-1997: 4$ & .96 & .92 \\
\hline $1998: 1-2015: 4$ & .49 & .54 \\
\hline $1970: 2-2015: 4$ & .65 & .73 \\
\hline \multicolumn{3}{|l|}{ 12. United States: } \\
\hline $1970: 2-1997: 4$ & 1.30 & .86 \\
\hline $1998: 1-2015: 4$ & .53 & .71 \\
\hline $1970: 2-2015: 4$ & 1.00 & .82 \\
\hline
\end{tabular}

Table 1 presents both the mean and standard deviation of inflation rate for all countries during three periods -- 1970 - 1997, 1998-2015, and 1970 -2015. Panel A of Table 1 presents monthly statistics and Panel B provides quarterly statistics.

As can be seen from the Panel A, both the mean and standard deviation of the inflation rate have declined for all countries after 1997. For example, the mean monthly inflation rate for Canada was .449\% during the 1970-1997 period, but it subsequently declined to $.156 \%$ during the $1998-2015$ period. The standard deviation of the inflation rate for Canada also declined from $.408 \%$ between $1970-1997$ to $.370 \%$ between 1998-2015. 
The results obtained with quarterly data, which are presented in Panel B of Table 2, are very similar to those obtained with monthly data. Both the mean quarterly inflation rate and the standard deviation of quarterly inflation rate have diminished perceptibly for all countries after 1997.

\section{EMPIRICAL RESULTS}

Table 2 presents the out-of-sample, one-period-ahead forecasts of inflation rate generated from the three forecasting models - ARIMA model, Phillips curve model and naïve model. Two alternative forecast error statistics - mean absolute error (MAE) and root mean square error (RMSE) - are computed for each forecasting model for all countries.

Before the Phillips curve model as specified by equation (2) is estimated, the lag lengths, $\beta(\mathrm{L})$ and $\gamma(\mathrm{L})$, in the equation must be specified. Several statistical procedures, such as Akaike Information Criterion (AIC) and Bayesian Information (or Schwartz) Criterion (BIC), can be invoked to specify the lag lengths in equation (2). Since the BIC always chooses a lag length that is not longer than that chosen by the AIC, the lag lengths chosen by the BIC are therefore imposed on equation (2) for all countries. For the sake of convenience, $\beta(\mathrm{L})$ is specified first and then $\gamma(\mathrm{L})$ is determined next. The order of lag specification does not affect the substantive results ${ }^{15}$.

Out-of-sample, one-period-ahead forecasts of inflation rate for all countries are generated for the last five years of the sample period. For example, in the case of Canada, all three forecasting models are estimated for the period 1998- 2010 and then out-of-sample forecasts of inflation rate for the period 20112015 are then generated from these estimated models. Panel A of Table 2 presents one-month-ahead forecasts of inflation rate and Panel B provides one-quarter-ahead forecasts of inflation rate. Again, due to the lack of monthly data for inflation rate for Australia, New Zealand and Switzerland, results for these countries are presented in Panel B only.

TABLE 2

\section{SUMMARY STATISTICS OF OUT-OF-SAMPLE, ONE-PERIOD-AHEAD INFLATION FORECASTS FROM THREE ALTERNATIVE MODELS OF INFLATION RATE: MONTHLY AND QUARTERLY RESULTS FOR THE PERIOD 1998-2015}

\begin{tabular}{lcc}
\hline & MAE & Summary Statistics \\
\hline A. Monthly Results: & & RMSE \\
1. Canada & & \\
ARIMA Model & .290 & .387 \\
Phillips Curve Model & .370 & .481 \\
Naïve Model & .359 & .475 \\
2. France & & \\
ARIMA Model & .309 & .381 \\
Phillips Curve Model & .446 & .553 \\
Naïve Model & .494 & .599 \\
& & \\
3. Germany & & .324 \\
ARIMA Model & .247 & .492 \\
Phillips Curve Model & .344 & .507 \\
Naïve Model & .354 & \\
\hline
\end{tabular}




\begin{tabular}{|c|c|c|}
\hline & \multicolumn{2}{|c|}{ Summary Statistics } \\
\hline & MAE & RMSE \\
\hline \multicolumn{3}{|l|}{ 4. Israel } \\
\hline ARIMA Model & .321 & .416 \\
\hline Phillips Curve Model & .344 & .429 \\
\hline Naïve Model & .368 & .452 \\
\hline \multicolumn{3}{|l|}{ 5. Japan } \\
\hline ARIMA Model & .233 & .364 \\
\hline Phillips Curve Model & .278 & .421 \\
\hline Naïve Model & .281 & .421 \\
\hline \multicolumn{3}{|l|}{ 6. South Korea } \\
\hline ARIMA Model & .224 & .289 \\
\hline Phillips Curve Model & .247 & .306 \\
\hline Naïve Model & .260 & .327 \\
\hline \multicolumn{3}{|l|}{ 7. Sweden } \\
\hline ARIMA Model & .297 & .405 \\
\hline Phillips Curve Model & .421 & .561 \\
\hline Naïve Model & .482 & .644 \\
\hline \multicolumn{3}{|l|}{ 8. United Kingdom } \\
\hline ARIMA Model & .256 & .342 \\
\hline Phillips Curve Model & .289 & .377 \\
\hline Naïve Model & .403 & .513 \\
\hline \multicolumn{3}{|l|}{ 9. United States } \\
\hline ARIMA Model & .296 & .350 \\
\hline Phillips Curve Model & .266 & .331 \\
\hline Naïve Model & .258 & .325 \\
\hline \multicolumn{3}{|l|}{ B. Quarterly Results: } \\
\hline \multicolumn{3}{|l|}{ 1. Australia } \\
\hline ARIMA Model & .336 & .463 \\
\hline Phillips Curve Model & .365 & .483 \\
\hline Naïve Model & .386 & .515 \\
\hline \multicolumn{3}{|l|}{ 2. Canada } \\
\hline ARIMA Model & .410 & .500 \\
\hline Phillips Curve Model & .533 & .653 \\
\hline Naïve Model & .533 & .647 \\
\hline \multicolumn{3}{|l|}{ 3. France } \\
\hline ARIMA Model & .391 & .433 \\
\hline Phillips Curve Model & .366 & .490 \\
\hline Naïve Model & .465 & .596 \\
\hline
\end{tabular}




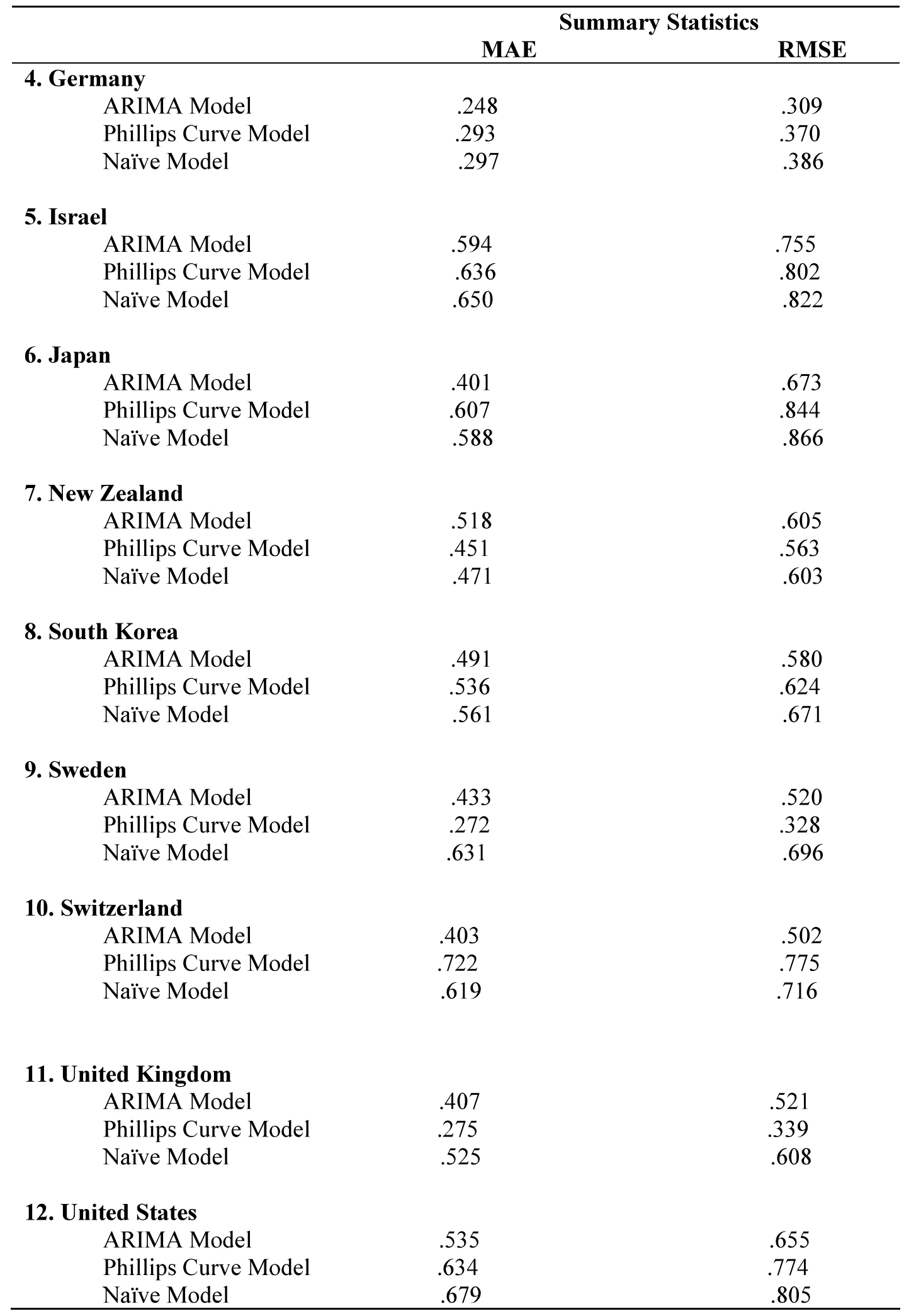

Note: The ARIMA model is characterized as an IMA $(1,1)$ process with the following specification: $\Pi_{\mathrm{t}}-\pi_{\mathrm{t}-1}=\mu+\varepsilon_{\mathrm{t}}-\theta \varepsilon_{\mathrm{t}-1}$, where $\pi_{\mathrm{t}}$ where is the inflation rate defined as $\log \left(\mathrm{p}_{\mathrm{t}} / \mathrm{p}_{\mathrm{t}-1}\right)$, $\mathrm{p}_{\mathrm{t}}$ is the CPI (Consumer Price Index) at time $t, \mu$ is a constant, and $\varepsilon_{t}$ is a random disturbance (white noise) term. The following version of the Phillips curve model of inflation rate is estimated: 
$\Delta \pi_{\mathrm{t}}=\alpha+\beta(\mathrm{L}) \Delta \mathrm{X}_{\mathrm{t}}+\gamma(\mathrm{L}) \Delta \pi_{\mathrm{t}}+\varepsilon_{\mathrm{t}}$, where $\pi_{\mathrm{t}}$ is the inflation rate at time $\mathrm{t}, \mathrm{X}_{\mathrm{t}}$ is the industrial production at time $\mathrm{t}$, and $\beta(\mathrm{L})$ and $\gamma(\mathrm{L})$ are lag operators representing the number of lagged (differenced ) industrial production and inflation rate variables, respectively. The naïve model is of the following form: $\pi_{t}=\pi_{t-1}$

It can be seen from Panel A of Table 2, the ARIMA model, based on both MAE and RMSE statistics, generates more accurate out-of-sample one-period-ahead monthly forecasts of inflation rate than either the Phillips curve model or the naïve model for all countries except the United States. Naïve model produces the most accurate one-month-ahead inflation forecasts for the United States. The quarterly results for these countries, as can be seen in Panel B, are quite similar to monthly results. Quarterly forecasts generated from the ARIMA model, based on both MAE and RMSE statistics, are most accurate for all countries except New Zealand, Sweden, and the United Kingdom. Phillips Curve model provides the most accurate one-quarter-ahead forecast of inflation rate for these three countries. Therefore, these findings indicate that ARIMA model delivers the most accurate one-month-ahead and one-quarter-ahead forecasts for the majority of countries during the period 1998-2015.

The predictive performance of one-year-ahead inflation forecasting models can be evaluated in the same manner. The lag lengths of the Phillips curve model, $\beta(\mathrm{L})$ and $\gamma(\mathrm{L})$ in equation (6), are specified via the BIC method prior to estimation. As before, out-of-sample, one-year-ahead forecasts of inflation rate, which are presented in Table 3, are extracted for the last 5 years of the sample period (2011-2015) for all countries. Two alternative forecast error statistics - mean absolute error (MAE) and root mean square error (RMSE) - are computed for all three models.

\section{TABLE 3 \\ SUMMARY STATISTICS OF OUT-OF-SAMPLE ONE-YEAR-AHEAD INFLATION FORECASTS FROM THREE ALTERNATIVE MODELS OF INFLATION RATE: MONTHLY AND QUARTERLY RESULTS FOR THE PERIOD 1998-2015}

\begin{tabular}{|c|c|c|}
\hline & \multicolumn{2}{|c|}{ Summary Statistics } \\
\hline & MAE & RMSE \\
\hline \multicolumn{3}{|l|}{ A. Monthly Results: } \\
\hline \multicolumn{3}{|l|}{ 1. Canada } \\
\hline ARIMA Model & .995 & 1.167 \\
\hline Phillips Curve Model & .930 & 1.139 \\
\hline Naïve Model & 1.096 & 1.423 \\
\hline \multicolumn{3}{|l|}{ 2. France } \\
\hline ARIMA Model & .576 & .708 \\
\hline Phillips Curve Model & .716 & .867 \\
\hline Naïve Model & .795 & 1.092 \\
\hline \multicolumn{3}{|l|}{ 3. Germany } \\
\hline ARIMA Model & .510 & .613 \\
\hline Phillips Curve Model & .557 & .711 \\
\hline Naïve Model & .753 & .976 \\
\hline \multicolumn{3}{|l|}{ 4. Israel } \\
\hline ARIMA Model & 1.123 & 1.373 \\
\hline Phillips Curve Model & 1.015 & 1.227 \\
\hline Naïve Model & 2.355 & 3.099 \\
\hline
\end{tabular}




\begin{tabular}{|c|c|c|}
\hline & & \\
\hline & MAE & RMSE \\
\hline 5. Japan & & \\
\hline ARIMA Model & 1.578 & 1.913 \\
\hline Phillips Curve Model & 1.700 & 2.076 \\
\hline Naïve Model & .998 & 1.403 \\
\hline 6. South Korea & & \\
\hline ARIMA Model & .919 & 1.198 \\
\hline Phillips Curve Model & .853 & 1.095 \\
\hline Naïve Model & 1.418 & 2.138 \\
\hline 7. Sweden & & \\
\hline ARIMA Model & .897 & 1.261 \\
\hline Phillips Curve Model & 1.010 & 1.398 \\
\hline Naïve Model & 1.221 & 1.653 \\
\hline 8. United Kingdom & & \\
\hline ARIMA Model & 1.130 & 1.292 \\
\hline Phillips Curve Model & 1.346 & 1.508 \\
\hline Naïve Model & .824 & 1.086 \\
\hline 9. United States & & \\
\hline ARIMA Model & .9891 & .194 \\
\hline Phillips Curve Model & 1.281 & 1.493 \\
\hline Naïve Model & 1.411 & 1.863 \\
\hline B. Quarterly Results: & & \\
\hline 1. Australia & & \\
\hline ARIMA Model & .921 & 1.100 \\
\hline Phillips Curve Model & .981 & 1.211 \\
\hline Naïve Model & 1.235 & 1.628 \\
\hline 2. Canada & & \\
\hline ARIMA Model & .933 & 1.087 \\
\hline Phillips Curve Model & .989 & 1.144 \\
\hline Naïve Model & 1.029 & 1.336 \\
\hline 3. France & & \\
\hline ARIMA Model & .552 & .678 \\
\hline Phillips Curve Model & .834 & .956 \\
\hline Naïve Model & .756 & 1.044 \\
\hline 4. Germany & & \\
\hline ARIMA Model & .472 & .558 \\
\hline Phillips Curve Model & .562 & .639 \\
\hline Naïve Model & .722 & .927 \\
\hline
\end{tabular}




\begin{tabular}{|c|c|c|}
\hline & & \\
\hline & MAE & RMSE \\
\hline 5. Israel & & \\
\hline ARIMA Model & 1.005 & 1.258 \\
\hline Phillips Curve Model & .988 & 1.056 \\
\hline Naïve Model & 2.299 & 3.028 \\
\hline 6. Japan & & \\
\hline ARIMA Model & 1.584 & 1.906 \\
\hline Phillips Curve Model & 1.568 & 1.847 \\
\hline Naïve Model & .968 & 1.371 \\
\hline 7. New Zealand & & \\
\hline ARIMA Model & 1.147 & 1.585 \\
\hline Phillips Curve Model & 1.365 & 1.909 \\
\hline Naïve Model & 1.316 & 1.662 \\
\hline 8. South Korea & & \\
\hline ARIMA Model & .871 & 1.132 \\
\hline Phillips Curve Model & .920 & 1.059 \\
\hline Naïve Model & 1.360 & 2.057 \\
\hline 9. Sweden & & \\
\hline ARIMA Model & .872 & 1.242 \\
\hline Phillips Curve Model & 1.035 & 1.393 \\
\hline Naïve Model & 1.174 & 1.587 \\
\hline 10. Switzerland & & \\
\hline ARIMA Model & .648 & .786 \\
\hline Phillips Curve Model & .832 & 1.035 \\
\hline Naïve Model & .852 & 1.144 \\
\hline 11. United Kingdom & & \\
\hline ARIMA Model & 1.132 & 1.275 \\
\hline Phillips Curve Model & 1.359 & 1.476 \\
\hline Naïve Model & .801 & 1.042 \\
\hline 12. United States & & \\
\hline ARIMA Model & .903 & 1.128 \\
\hline Phillips Curve Model & 1.082 & 1.325 \\
\hline Naïve Model & 1.305 & 1.758 \\
\hline
\end{tabular}

Note: The ARIMA model is characterized as an IMA $(1,1)$ process with the following specification:

$\Pi_{t+h, t}-\pi_{t}=\mu+\varepsilon_{t}-\theta \varepsilon_{t-1}$, where $\Pi_{t+h, t}$, one-year-ahead inflation rate, is defined as $\log \left(\mathrm{p}_{\mathrm{t}+12} / \mathrm{p}_{\mathrm{t}}\right)$ for the monthly forecasting model and as $\log \left(\mathrm{p}_{\mathrm{t}+4} / \mathrm{p}_{\mathrm{t}}\right)$ for the quarterly forecasting model. $\pi_{\mathrm{t}}$, annualized inflation rate, is defined as $\log \left(\mathrm{p}_{\mathrm{t}} / \mathrm{p}_{\mathrm{t}-12}\right)$ for the monthly forecasting model and as $\log \left(\mathrm{p}_{\mathrm{t}} / \mathrm{p}_{\mathrm{t}-4}\right)$ for the quarterly forecasting model. The following version of the Phillips curve model of inflation rate is estimated:

$\Pi_{\mathrm{t}+\mathrm{h}, \mathrm{t}}-\pi_{\mathrm{t}}=\alpha+\beta(\mathrm{L}) \Delta \mathrm{X}_{\mathrm{t}}+\gamma(\mathrm{L}) \Delta \pi_{\mathrm{t}}+\varepsilon_{\mathrm{t}}$, where $\mathrm{X}_{\mathrm{t}}$ is the industrial production variable at time $\mathrm{t}$, and $\beta(\mathrm{L})$ and $\gamma(\mathrm{L})$ are lag operators representing the number of lagged (differenced ) industrial production and inflation rate variables, respectively. Naïve model is expressed as follows: $\Pi_{\mathrm{t}+\mathrm{h}, \mathrm{h}}=\pi_{\mathrm{t}}$. 
Panels A and B of Table 3 provide one-year-ahead inflation forecasts generated from three alternative models using monthly data and quarterly data, respectively. It can be seen from Panel A that the ARIMA model yields the most accurate one-year-ahead forecasts of monthly inflation rate for only France, Germany, Sweden, and the United States. Monthly inflation forecasts derived from the Phillips Curve model fare best for Canada, Israel, and South Korea. Naïve model provides the most accurate forecasts of monthly inflation rate for Japan and the United Kingdom. Therefore, no model was able to generate superior one-year-ahead monthly inflation forecasts for the majority of nine countries, although the ARIMA model fares best for 4 out of the 9 countries.

As can be seen from Panel B, the ARIMA model yields the most accurate one-year-ahead quarterly inflation forecasts for all countries except Israel, Japan and the United Kingdom. The Phillips Curve model provides the most accurate one-year-ahead quarterly inflation rate forecasts for Israel, and the naïve model generates the most accurate quarterly inflation forecast for Japan and the United Kingdom.

It can be concluded from these results that, regardless of the frequency of data employed and the duration of the forecasting horizon, the ARIMA model yields superior inflation forecasts for the majority of countries during the period 1998-2015. These results are clearly attributable to both the lower inflation rate and inflation volatility experienced by the twelve countries during this period.

\section{CONCLUSION}

This paper has attempted to shed an important light on the timely issue of whether a prolonged period of relatively stable inflation has a tangible impact on the predictive performance of various inflation forecasting models. This study has compared the predictive performance of three alternative inflation forecasting models - ARIMA model, Phillips curve model and naïve model - for twelve countries, seven of which are explicitly targeting inflation rate, over the period 1998-2015, a period marked by relatively subdued inflation rate. It is found that ARIMA model yields superior forecasts for the majority of these countries during this period.

The central bank must be able to predict the future course of the inflation rate with some degree of accuracy in order to render its monetary policy effective, given there exists long and variable lags for the monetary policy to exert a significant influence on the real economic activity. Central banks customarily utilize inflation forecasts from a wide range of empirical models. In view of the findings of this study, it behooves the central bank to weigh inflation forecasts from the ARIMA model more heavily in its decision-making process during the period of low and stable inflation rate. This advice is especially timely since it is widely expected that the inflation rate for both industrialized and emerging countries will continue to remain at a relatively subdued level (between $2 \%-3 \%$ ) for the foreseeable future.

\section{ENDNOTES}

1. Average Annual Inflation by Decades, InflationData.com, June $18^{\text {th }}, 2015$.

2. International Financial Statistics (IFS) Database, IMF.

3. "Why is Inflation So Low?", Peterson Institute for International Economics (PIIE), June 28 $8^{\text {th }}, 2015$.

4. "How Globalization Helped Decreasing Inflation", Roubini EconoMonitor, August $5^{\text {th }}, 2013$.

5. "Why is Inflation Falling Everywhere?", World Economic Forum, August $17^{\text {th }}, 2015$.

6. "Why is Inflation So Low?", Peterson Institute for International Economics (PIIE), June 28 $8^{\text {th }}, 2015$.

7. Bernanke, Laubach, Mishkin and Posen (1999) and Mishkin and Schmidt-Hebbel (2007) document that inflation targeting reduces inflation rate, inflation volatility, interest rates and output growth volatility for all countries that adopted this strategy. Specifically, Mishkin and Schmidt-Hebbel (2007) show that the average annual inflation rate for inflation targeting countries has dropped from $12.6 \%$ to $4.4 \%$ after these countries have formally adopted inflation targeting.

8. The term "secular stagnation" was originally introduced by Alvin Hansen in 1938 to describe a condition of negligible or no economic growth for a prolonged period of time. Economic growth rate in the United States and other countries have remained at a very low level for quite some time and it is widely predicted that such level will continue to persist in the future. Stagnant economic condition can be ascribed to the 
tepid growth in aggregate demand as a result of insufficient expansionary macroeconomic policy [see Larry Summers (2015)] and the lackluster growth in aggregate supply due to demographic changes (e.g., low birth rate and aging population), declining labor force participation, and diminishing labor productivity [see Robert Gordon (2015)].

9. The first country to formally adopt inflation targeting policy was New Zealand (1990), followed by Canada (1991), Chile (1991), Israel (1992), United Kingdom (1992), Peru (1994), Australia (1994), Sweden (1995), South Korea (1998), and Brazil (1999). Nineteen other countries have implemented inflation targeting policy since 2000 .

10. New Zealand adopted inflation targeting to eradicate a double-digit inflation rate that had persistently plagued the country between 1974 and 1988. Australia, Israel and the United Kingdom adopted inflation targeting to mitigate the impact of exchange rate volatility on the economy. Sweden switched from exchange-rate targeting to inflation targeting in 1992 to stimulate its moribund economy as the country was mired in lingering recession from 1991 to 1992. South Korea adopted inflation targeting policy in April 1998 in the aftermath of the Asian financial crisis of 1997-98.

11. Phillips curve models are traditionally characterized as a relationship between changes in inflation rate to past values of unemployment gap, i.e., the gap between unemployment rate and the non-accelerating inflation rate of unemployment (NAIRU), and past changes in inflation rate.

12. The HICP, European Union's official consumer price index, differs from the US CPI in two fundamental respects. First, the HICP includes rural population in the sample while the US CPI is based on a survey exclusive of urban population. Second, the HICP excludes owner-occupied housing in its survey as it deems such expenditures as investment. The US CPI includes "rental-equivalent" costs as a proxy for owner-occupied housing.

13. Refer to Bernanke and Mishkin (1997) and Bernanke, Laubach, Mishkin and Posen (1999) for their discussion on the merits of implementing inflation targeting policy.

14. Source: Bank of Japan's website.

15. Although the final specification of the lag lengths, $\beta(L)$ and $\gamma(L)$, in the equations (2) and (6) are not reported in this paper, these results will be available from the author upon request.

\section{REFERENCES}

Ang, A., Bekaert, G., \& Wei, M (2007). Do Macro Variables, Asset Markets or Surveys Forecast Inflation Better? Journal of Monetary Economics, 54, 1163-1212.

Atkeson, A., \& Ohanian, L. (2001). Are Phillips Curves Useful for Forecasting Inflation? Federal Reserve Bank of Minneapolis Quarterly Review, 25(1), 2-11.

Bernanke, B.S. \& Mishkin, F.S. (1997). Inflation Targeting: A New Framework for Monetary Policy? Journal of Economic Perspectives, 11, 97-116.

Bernanke, B.S., Laubach, T., Mishkin, F.S., \& Posen, A.S. (1999). Inflation Targeting: Lessons from the International Experience, Princeton University Press, Princeton, New Jersey.

Edge, R.M., \& Gurkaynak, R. (2010). How Useful Are Estimated DSGE Model Forecasts for Central Bankers? Brookings Papers on Economic Activity, 209-259.

Fisher, J.D.M., Liu, C.T., \& Zhou, R. (2002). When can we forecast inflation? Economic Perspectives, Federal Reserve Bank of Chicago, 30-42.

Gordon, R. J. (2015) Secular Stagnation: A Supply-Side View. American Economic Review, Papers and Proceedings, 105, 54-59.

Hafer, R.W., \& Hein, S.E. (1985). On the Accuracy of Time-Series, Interest Rate, and Survey Forecasts of Inflation. Journal of Business, 58, 377-398.

Hafer, R.W., \& Hein, S.E. (1990). Forecasting Inflation using Interest-Rate and Time-Series Models: Some International Evidence. Journal of Business, 63, 1-17.

International Monetary Fund. (2005). World Economic Outlook. Washington.

Mishkin, F.S., \& Schmidt-Hebbel, K. (2007). Does Inflation Targeting Make a Difference? NBER Working Paper Series, \# 12876.

Orphanides, A., \& van Norden, S. (2005). The Reliability of Inflation Forecast based on Output Gap Estimates in Real Times. Journal of Money, Credit, and Banking, 37, 583-600. 
Stock, J.H., \& Watson, M.W. (1999). Forecasting Inflation. Journal of Monetary Economics, 44, 293335.

Stock, J.H., \& Watson, M.W. (2007). Why has U.S. Inflation Become Harder to Forecast? Journal of Money, Credit and Banking, 39, 3 -34.

Summers, L. (2015). Demand Side Secular Stagnation. American Economic Review, Papers and Proceedings, 105, 60-65. 